\title{
UJI PENENTUAN NILAI SPF (Sun Protection Factor) FRAKSI BUNGA ROSELA (Hibiscus Sabdariffa L.) SEBAGAI ZAT AKTIF TABIR SURYA
}

\author{
Determination of sun protection factor (SPF) on \\ fractionated extract of Rosela (Hibiscus Sabdariffa L.) as \\ sunscreen active agent \\ Vivin Nopiyanti' ${ }^{1}$, Siti Aisiyah ${ }^{2)}$ \\ vivinnopiyanti@gmail.com \\ ${ }^{1}$ Laboratorium Instrumentasi, S1 Farmasi, Fakultas Farmasi, Universitas Setia Budi,Surakarta \\ ¿Laboratorium Teknologi Farmasi, S1 Farmasi, Fakultas Farmasi, Universitas Setia Budi, Surakarta
}

\begin{abstract}
Abstrak
Sun Protection Factor atau SPF didefinisikan sebagai perbandingan antara banyaknya energi sinar surya (dalam hal ini UV-B) yang dibutuhkan untuk menimbulkan eritema minimal pada kulit yang dilindungi tabir surya dengan yang tidak dilindungi tabir surya. Bunga rosela mengandung flavonoid, antosian, dan polifenol. Senyawa flavonoid mempunyai potensi sebagai tabir surya karena memiliki gugus kromofor (ikatan rangkap tunggal terkonjugasi) yang mampu menyerap sinar UV-A maupun UV-B sehingga mengurangi intensitas pada kulit. Penelitian ini dilakukan untuk mengetahui berapa nilai SPF dari fraksi n-heksana, fraksi etil asetat dan fraksi air dari bunga rosela. Dan diketahui fraksi yang mempunyai nilai SPF tertinggi yang bisa dimanfaatkan sebagai tabir surya.

Bunga rosela dibuat ekstrak kemudian difraksinasi dengan pelarut n-heksana, etil asetat dan air. Fraksi yang dihasilkan berupa fraksi nheksana, fraksi etil asetat dan fraksi air serta ekstrak tersebut diukur nilai SPF nya. Pengukuran SPF dapat dilakukan secara in vitro dengan menggunakan spektrofotometri UV- Vis. Pengujian secara in vitro berguna untuk tes pendahuluan dalam proses pengembangan produk tabir surya.

Nilai SPF dari ekstrak etanol $70 \%$, fraksi n-heksana, fraksi etil asetat dan fraksi air dari ekstrak bunga rosela yaitu berturut-turut $6,63 \pm 0,23$; $10,11 \pm 0,61 ; 13,83 \pm 1,50 ; 11,15 \pm 0,47$. Fraksi etil asetat adalah fraksi yang mempunyai nilai SPF tertinggi yang bisa dimanfaatkan sebagai tabir surya.

Keywords : SPF, fraksi, Hibiscus sabdariffa L.
\end{abstract}

\section{Abstract}

Sun Protection Factor or SPF is defined as the ratio between the amount of sunlight energy (in this case UV-B) needed to cause minimal erythema on sun-protected skin with the amount of energy needed to cause minimal erythema on skin that is not protected by sunscreen. Rosela flowers contain flavonoids, anthocyanes, and polyphenols. Flavonoids compound have the potential as sunscreens because they have a chromophore group (single conjugated double bond) that is able to absorb UV-A and UV-B rays so that it reduces the intensity of the skin. This research was conducted to find out the SPF value of the $n$-hexane fraction, the ethyl acetate fraction and the water fraction from the rosela flower. And it is known that the faction that has the highest SPF value can be used as sunscreen.

Rosela flower extract then fractionated with $n$ hexane, ethyl acetate and water solvents. The resulting fractions in the form of $n$-hexane fraction, ethyl acetate fraction and water and extract fractions were measured for their SPF values. SPF measurements can be done in vitro using UV-Vis spectrophotometry. In vitro testing was useful for preliminary tests in the process of developing sunscreen products.

The SPF value of the extract, the n-hexane fraction, the ethyl acetate fraction and the water fraction from the rosela flower extract, respectively 
$6,63 \pm 0,23 ; 10,11 \pm 0,61 ; 13,83 \pm 1,50 ; 11,15 \pm 0,47$. The ethyl acetate fraction was the fraction that has the highest SPF value that can be used as a sunscreen.

Keywords: SPF, fraction, Hibiscus sabdariffa $L$.

\section{Pendahuluan}

Sinar matahari merupakan sumber energi bagi kelangsungan hidup semua makhluk di bumi, namun pada paparan berlebih di kulit akan memberikan derajat kerusakan yang tergantung pada frekuensi dan lamanya sinar matahari mengenai kulit. Kemampuan menahan sinar ultraviolet dari sediaan tabir surya dinilai sebagai factor proteksi sinar (Sun Protecting Factor/SPF) (Mulyani dkk, 2015). SPF didefinisikan sebagai perbandingan antara banyaknya energi sinar surya (dalam hal ini UVB) yang dibutuhkan untuk menimbulkan eritema minimal pada kulit yang dilindungi tabir surya dengan yang tidak dilindungi tabir surya. Pengukuran SPF dapat dilakukan secara in vitro dengan menggunakan spektrofotometri UVVis. Pengujian secara in vitro berguna untuk tes pendahuluan dalam proses pengembangan produk tabir surya (Shovyana, 2013).

Bunga rosela mengandung flavonoid, antosian, dan polifenol (Kuriyan et al., 2010). Senyawa aktif dari bunga rosela yaitu antosianin berupa 3-sambubioside, protein, lemak, serat, kalsium, fosfor, besi, karoten, tiamin, riboflavin, dan niasin selain itu asam askorbat dan fenol (Maryani dan Kristiana, 2008). Antosianin merupakan suatu senyawa yang memiliki sistem ikatan rangkap terkonjugasi yang berperan mencegah kerusakan sel akibat paparan sinar UV berlebih. Senyawa flavonoid juga mempunyai potensi sebagai tabir surya karena memiliki gugus kromofor (ikatan rangkap tunggal terkonjugasi) yang mampu menyerap sinar UVA maupun UV-B sehingga mengurangi intensitas pada kulit (Rahmawati, 2012).

Berdasarkan latar belakang tersebut maka perlu dilakukan penelitian untuk mengetahui berapa nilai SPF dari fraksi nheksana, fraksi etil asetat dan fraksi air dari ekstrak bunga rosela. Dan diketahui fraksi yang mempunyai nilai SPF tertinggi yang bisa dimanfaatkan sebagai tabir surya.

\section{Metode Penelitian}

Alat

Alat-alat yang digunakan dalam penelitian ini meliputi blender, mesh no. 40, timbangan, timbangan analitik, Sterling-Bidwel, corong Buchner, oven, evaporator, alat-alat gelas, botol maserasi, lemari pendingin, timbang analitik.

Bahan

Bahan utama yang digunakan dalam penelitian ini adalah bunga rosela, pelarut etanol $70 \%, \mathrm{~N}$ heksan, etil asetat.

\section{Tahapan Penelitian}

Determinasi tanaman rosela

Determinasi dilakukan di laboratorium Morfologi dan sistematika Tumbuhan, Universitas Setia Budi. Determinasi bertujuan untuk menetapkan kebenaran yang berkaitan dengan ciri-ciri makroskopis berdasarkan studi pustaka.

\section{Persiapan bahan baku kelopak bunga} rosela

Kelopak bunga rosela yang telah dipanen kemudian dicuci bersih dengan air mengalir untuk menghilangkan kotoran dan cemaran, ditiriskan dan disortir yang memenuhi persyaratan. Kemudian ditimbang berat basah kelopak bunga rosela tersebut.

Pengeringan dan pembuatan serbuk

Selanjutnya dikeringkan dengan oven pada suhu $40^{\circ}$ C. Setelah kering ditimbang. Pembuatan serbuk menggunakan alat penyerbuk, kemudian diayak dengan ayakan ukuran 60 mesh. Hasil penyerbukan yang berupa serbuk kering disimpan dalam wadah kering dan tertutup rapat yang selanjutnya digunakan untuk penelitian.

Penetapan susut pengeringan serbuk bunga rosela

Penetapan susut pengeringan serbuk bunga rosela pada penelitian ini dilakukan menggunakan alat moisture balance, Dilakukan pengambilan data sebanyak 3 kali. Angka yang muncul dalam satuan persen pada alat moisture balance dicatat sebagai kadar susut pengeringan. Pembuatan ekstrak dari kelopak bunga rosela

Pembuatan ekstrak dengan cara maserasi dengan menggunakan pelarut etanol $70 \%$ dengan perbandingan 1:10.Serbuk bunga rosela sebanyak 500 gram dengan pelarut yang dipakai 5000ml. Serbuk bunga rosela sebanyak 500 gram dimasukkan ke dalam botol, dengan ditambahkan pelarut etanol 70\% sebanyak 3750 
$\mathrm{ml}$ ekstraksi awal rasio serbuk dengan pelarut 1:7,5 dilakukan selama 5 hari dengan sesekali digojog berulang-ulang. Maserat yang didapatkan selama 5 hari diperas dengan kain flanel dan disaring. Residu kemudian

dengan menggunakan rotary evaporator pada suhu $50^{\circ} \mathrm{C}$ hingga diperoleh ekstrak kental (Depkes 1986).

\section{Fraksinasi dari ekstrak etanol bunga rosela}

Fraksinasi dari ekstrak etanol bunga rosela dibuat dengan cara ditimbang dari ekstrak kental hasil maserasi. Ekstrak kental yang sudah ditimbang dilarutkan dengan etanol dan aquadestilata kemudian dipisahkan di corong pisah dengan ditambahkan n-heksan, dipartisi sebanyak tiga kali. Hasil fraksinasi yang diperoleh dipekatkan dengan rotary evaporator dan disebut sebagai fraksi n-heksan.

Residu dari fraksinasi n-heksan dipisahkan di corong pisah dengan ditambahkan etil asetat, dipartisi sebanyak tiga kali. Hasil fraksinasi yang diperoleh dipekatkan dengan menggunakan rotary evaporator kemudian ditimbang dan disebut sebagai fraksi etil asetat.

Hasil residu dari fraksi etil asetat ( fraksi air) dipekatkan dengan cara dibiarkan menguap pada suhu kamar, karena masih terdapat kandungan air yang cukup banyak maka dipekatkan kembali menggunakan waterbath suhu $\pm 50^{\circ} \mathrm{C}$ lalu ditimbang dan disebut sebagai fraksi air.

\section{a. Pengujian kandungan kimia ekstrak bunga rosela}

Identifikasi kandungan kimia dimaksudkan untuk menetapkan kebenaran kandungan kimia yang terdapat dalam ekstrak bunga rosela dan juga fraksi teraktif dari ekstrak bunga rosela

Identifikasi flavonoid. Identifikasi flavonoid dilakukan dengan cara mengambil ekstrak sebanyak $\pm 0,1 \mathrm{~g}$ dicampurkan dengan aquadestilata. Setelah itu, didihkan selama 5 menit kemudian disaring. Filtrat ditambahkan 0,5 $\mathrm{mg}$ bubuk $\mathrm{Mg}$ dan ditambahkan $1 \mathrm{ml} \mathrm{HCl}$ pekat dan amil alkohol. Dicampur dan dikocok kuat-kuat kemudian dibiarkan memisah. Reaksi positif ditandai dengan warna merah atau kuning atau jingga pada lapisan amil akohol (Alamsyah 2014).

Identifikasi alkaloid. Ekstrak sebanyak \pm 0,1 g dilarutkan dengan akuades. Setelah itu ditambahkan $1 \mathrm{ml} \mathrm{HCl} 2 \mathrm{~N}$. Dibuat dalam 2 tabung. Tabung 1 ditambahkan reagen Mayer terbentuk endapan menggumpal warna putih ditambahkan etanol $70 \%$ sebanyak $1250 \mathrm{ml}$ atau rasio 1:2,5 dimasukkan ke dalam botol dengan sekali diaduk dan dibiarkan selama 2 hari. Ekstrak yang diperoleh diuapkan pelarutnya

kekuningan. Tabung 2 ditambahkan reagen Dragendroff terbentuk endapan berwarna merah sampai jingga (Alamsyah 2014).

Identifikasi saponin. Ekstrak sebanyak \pm 0,1 g ditambahkan akuades, kemudian dipanaskan selama 2 sampai 3 menit. Setelah dipanaskan tunggu sampai dingin lalu kocok dengan kuat. Adanya busa yang stabil dan setelah ditambahkan 1 tetes $\mathrm{HCl} 2 \mathrm{~N}$ busa tidak hilang menandakan adanya kandungan saponin (Ramyashree et al. 2012).

Identifikasi tannin. Ekstrak sebanyak \pm 0,1 g ditambah dengan $20 \mathrm{ml}$ air panas kemudian dididihkan selama 15 menit setelah dingin disaring, Filtrat sebanyak $5 \mathrm{ml}$ dimasukkan ke dalam tabung reaksi, kemudian ditambahkan pereaksi larutan atau reagen Besi (III) Klorida1\%. Hasil positif tannin jika terbentuk warna hijau violet (Harborne, 1996).

Identifikasi Antosian. Ekstrak sebanyak $\pm 0,1 \mathrm{~g}$ ditambah dengan $\mathrm{HCl} 2 \mathrm{M}$ dipanaskan selama 5 menit pada $100{ }^{\circ} \mathrm{C}$, positif antosian warna tidak akan pudar (Harborne, 1996)

\section{b. Penentuan Nilai SPF fraksi n-heksana,} etil asetat dan air dari Esktrak rosela.

Ekstrak etanol rosela dan fraksi masingmasing diambil sebanyak 0,0125 g Kemudian diencerkan dengan etanol $70 \%$ hingga $50 \mathrm{ml}$. Larutan etanol 70\% dipakai sebagai blanko. Hasil absorbansi sampel pada panjang gelombang 290320 dengan interval $5 \mathrm{~nm}$ dicatat dan kemudian nilai SPFnya dihitung. Dilakukan sebanyak 3 kali replikasi. Metode spektrofotometri menggunakan pengenceran dengan kalkulasi nilai SPF menggunakan metode Mansur.

Analisis Data Nilai SPF dianalisis menggunakan metode Mansur : Keterangan : EE : Erythemal effect spectrum

I : Solar intensity spectrum

Abs : Absorbance of sunscreen product

$\mathrm{CF}$ : Correction factor $(=10)$

Nilai EE X I adalah konstan dan ditunjukkan pada Tabel 1 berikut :

Tabel 1. Normalized product function digunakan pada kalkulasi SPF

\begin{tabular}{|c|c|c|}
\hline No & $\begin{array}{c}\text { Panjang Gelombang } \\
(\mathrm{nm})\end{array}$ & EExI \\
\hline 1 & 290 & 0,0150 \\
\hline 2 & 295 & 0,0817 \\
\hline
\end{tabular}




\begin{tabular}{|c|c|c|}
\hline 3 & 300 & 0,2874 \\
\hline 4 & 305 & 0,3278 \\
\hline 5 & 310 & 0,1864 \\
\hline 6 & 315 & 0,0839 \\
\hline 7 & 320 & 0,0180 \\
\hline & Total & 1 \\
\hline
\end{tabular}

Cara perhitungan :

1. Nilai serapan yang diperoleh

dikalikan dengan nilai EE x I untuk

\section{HASIL DAN PEMBAHASAN}

Hasil determinasi yang didapat berdasarkan data dari laboratorium Morfologi dan sistematika Tumbuhan, Universitas Setia Budi menurut Steenis C.G.G.J.V, Bloembergen, H. Eyma, P.J. 1992 adalah benar Hibiscus sabdariffa $\mathrm{L}$.

Kelopak bunga rosela yang dipanen sebanyak $2 \mathrm{~kg}$, kemudian dicuci bersih dengan air masing-masing panjang gelombang yang terdapat pada tabel diatas.

2. Hasil perkalian serapan dan EE x I dijumlahkan.

3. Hasil penjumlahan kemudian dikalikan dengan faktor koreksi yang nilainya 10 untuk mendapatkan nilai SPF sampel.

mengalir untuk menghilangkan kotoran dan cemaran, ditiriskan dan disortir yang memenuhi persyaratan. Kemudian ditimbang berat basah kelopak bunga rosela tersebut didapatkan berat basah 1,8 kg.

Hasil penyerbukan yang berupa serbuk kering $1 \mathrm{~kg}$ kemudian disimpan dalam wadah kering dan tertutup rapat yang selanjutnya digunakan untuk penelitian.

Penetapan susut pengeringan serbuk kelopak bunga rosela menggunakan alat moisture balance. penetapannya tercantum pada tabel 2 di bawah ini:

Tabel 1. Hasil penetapan susut pengeringan serbuk kelopak bunga rosela

\begin{tabular}{ccc}
\hline No & Bobot serbuk (gram) & Susut pengeringan (\%) \\
\hline 1 & 2,00 & 6,5 \\
2 & 2,00 & 6,5 \\
3 & 2,00 & 6,0 \\
\hline & Rata- rata & 6,34
\end{tabular}

Hasil penetapan susut pengeringan serbuk kelopak bunga rosela didapatkan rata-rata sebesar 6,34 \%. Susut pengeringan memenuhi syarat di mana susut pengeringan serbuk simplisia tidak boleh lebih dari 10\%, karena Hasil pembuatan ekstrak etanol bunga rosela dari serbuk kelopak bunga rosela dengan berat 300gram setelah menjadi ekstrak didapatkan Fraksinasi dari ekstrak etanol bunga rosela

Hasil Fraksinasi dari ekstrak etanol bunga rosela 10 gram didapatkan fraksi N- heksan

\section{Hasil identifikasi kandungan kimia ekstrak} etanol bunga Rosela dengan susut pengeringan kurang dari 10\% sel dalam keadaan mati, enzim tidak aktif serta bakteri dan jamur tidak tumbuh sehingga bahan lebih awet (Katno et al. 2008).

berat 66,7127 gram. Rendemen ekstrak etanol kelopak bunga rosela adalah 22,23\%.

sebanyak 0,5038 gram, fraksi etil asetat 1,5024 gram dan fraksi air 2,8176 gram. Hasil rendemen fraksi $n$ heksan $0,50 \%$, fraksi etil asetat $15,02 \%$ dan fraksi air 28,18\%.

Tabel 4. Hasil identifikasi kandungan kimia ekstrak etanol bunga rosela

\begin{tabular}{llll}
\hline Senyawa & Hasil & Pustaka & Ket \\
\hline
\end{tabular}




\begin{tabular}{|c|c|c|}
\hline Flavonoid & $\begin{array}{l}\text { Warna kuning pada } \\
\text { lapisan amil alkohol. }\end{array}$ & $\begin{array}{l}\text { Reaksi positif ditandai dengan warna merah }(+) \\
\text { atau kuning atau jingga pada lapisan amil } \\
\text { alkohol (Alamsyah et al. 2014). }\end{array}$ \\
\hline Alkaloid & $\begin{array}{l}\text { Tabung } 1 \rightarrow \text { Tidak } \\
\text { terbentuk Endapan } \\
\text { putih kekuningan } \\
\text { (Reagen Mayers). } \\
\text { Tabung } 2 \rightarrow \text { Tidak } \\
\text { terjadi Endapan merah } \\
\text { kecoklatan (Reagen } \\
\text { Dragendroff) }\end{array}$ & $\begin{array}{l}\text { Terbentuk endapan menggumpal warna } \\
\text { putih kekuningan pada reagen Mayer dan } \\
\text { terbentuk endapan berwarna merah sampai } \\
\text { jingga kecoklatan pada reagen Dragendroff } \\
\text { (Alamsyah et al. 2014). }\end{array}$ \\
\hline Saponin & $\begin{array}{l}\text { Terbentuk busa yang } \\
\text { stabil }+1 \text { tetes } \mathrm{HCl} 2 \mathrm{~N} \\
\text { busa tidak hilang. }\end{array}$ & $\begin{array}{l}\text { Terbentuk busa yang stabil }+1 \text { tetes } \mathrm{HCl} \\
\text { 2N busa tidak hilang (Ramyashree } \text { et al. } \\
\text { 2012). }\end{array}$ \\
\hline Tanin & $\begin{array}{l}\text { Terbentuk warna hijau } \\
\text { violet }\end{array}$ & $\begin{array}{l}\text { Hasil positif tannin jika terbentuk warna }(+) \\
\text { hijau violet (Depkes 1995). }\end{array}$ \\
\hline Antosian & $\begin{array}{l}\text { Terbentuk warna } \\
\text { merah, warna tidak } \\
\text { pudar }\end{array}$ & $\begin{array}{l}\text { Hasil positif antosian warna tidak akan pudar } \quad(+) \\
\text { (Harborne, 1996). }\end{array}$ \\
\hline
\end{tabular}

Hasil identifikasi kandungan senyawa kimia ekstrak etanol positif mengandung senyawa flavonoid, saponin, tannin dan antosian.

Penentuan Nilai SPF fraksi n heksana, etil asetat dan air dari Esktrak rosela.

Tabel 5. Hasil Absorbansi dan nilai SPF masing-masing sampel

\begin{tabular}{|l|l|l|l|l|l|l|l|l|}
\hline No & Sampel & \multicolumn{7}{|c|}{ Panjang Gelombang (nm) } \\
\cline { 3 - 9 } & & 290 & 295 & 300 & 305 & 310 & 315 & 320 \\
\hline 1 & Ekstrak & 0,4838 & 0,4568 & 0,4271 & 0,3976 & 0,3791 & 0,3742 & 0,3752 \\
\hline 2 & $\begin{array}{l}\text { Fraksi } \\
\text { N- } \\
\text { heksana }\end{array}$ & 0,7827 & 0,7117 & 0,6798 & 0,6367 & 0,5984 & 0,5932 & 0,5729 \\
\hline 3 & $\begin{array}{l}\text { Fraksi } \\
\text { etil } \\
\text { asetat }\end{array}$ & 0,8452 & 0,8138 & 0,7679 & 0,7262 & 0,7055 & 0,7062 & 0,7218 \\
\hline 4 & $\begin{array}{l}\text { Fraksi } \\
\text { air }\end{array}$ & 0,9151 & 0,8306 & 0,7509 & 0,6880 & 0,6437 & 0,6167 & 0,6017 \\
\hline
\end{tabular}

Dengan konsentrasi yang sama dilihat hasil absorbansi menunjukkan absorbansi ekstrak paling rendah diantara fraksi-fraksi. Hal ini pengaruh dari kandungan senyawa kimia dari ekstrak dan fraksi pada kelopak bunga rosela.

Tabel 6. Hasil nilai SPF dari ekstrak etanol, fraksi $n$ heksana, fraksi etil asetat dan fraksi air kelopak bunga rosela

\begin{tabular}{|l|l|l|l|l|l|}
\hline & ekstrak & $\begin{array}{l}\text { Fraksi } \\
\text { heksana }\end{array}$ & $\begin{array}{l}\text { Fraksi etil } \\
\text { asetat }\end{array}$ & Fraksi air \\
\hline $\begin{array}{l}\text { SPF } \\
\text { pada }\end{array}$ & $6,63 \pm 0,23$ & $10,11 \pm 0,61$ & $13,83 \pm 1,50$ & $11,15 \pm 0,47$ \\
\hline
\end{tabular}

Hasil absorbansi dari masing-masing ekstrak dan fraksi bisa dilihat pada tabel 5 sebagai berikut:
Hasil perhitungan nilai SPF bisa dilihat pada tabel 6 . 


\begin{tabular}{|l|l|l|l|l|}
\hline $\begin{array}{l}290-320 \\
\mathrm{~nm}\end{array}$ & & & & \\
\hline
\end{tabular}

Hasil nilai SPF berturut-turut dari ekstrak etanol, fraksi $n$ hexana, fraksi etil asetat dan fraksi air adalah sebagai berikut 6,63 $\pm 0,23$; $10,11 \pm 0,61 ; 13,83 \pm 1,50 ; 11,15 \pm 0,47$. Nilai SPF paling tinggi pada fraksi etil asetat.
Kategori proteksi tabir surya berdasarkan nilai SPF menurut Damogalad et al. 2013 bisa dilihat pada tabel 7.

Tabel 7. Efektifitas tabir surya berdasarkan nilai SPF

\begin{tabular}{cl}
\hline SPF & Kategori Proteksi tabir surya \\
\hline $2-4$ & Proteksi minimal \\
$4-6$ & Proteksi sedang \\
$6-8$ & Proteksi ekstra \\
$8-15$ & Proteksi maksimal \\
$\geq 15$ & Proteksi ultra \\
\hline
\end{tabular}

Hasil nilai SPF nilai fraksi $\mathrm{n}$ heksana, fraksi etil asetat dan fraksi air termasuk dalam kategori proteksi maksimal karena berada pada range SPF 8-15 yaitu 10,11 $\pm 0,61 ; \quad 13,83 \pm 1,50$;
$11,15 \pm 0,47$ sedang nilai SPF ekstrak 6,63 $\pm 0,23$ masuk kategori proteksi ekstra,

Kandungan senyawa kimia fraksi etil asetat dari ekstrak etanol kelopak bunga rosela.

Tabel 8. Kandungan senyawa kimia fraksi etil asetat ekstrak kelopak bunga rosela

\begin{tabular}{|c|c|c|c|}
\hline Senyawa & Hasil & Pustaka & Ket \\
\hline Flavonoid & $\begin{array}{l}\text { Warna kuning pada } \\
\text { lapisan amil alkohol. }\end{array}$ & $\begin{array}{l}\text { Reaksi positif ditandai dengan warna merah } \\
\text { atau kuning atau jingga pada lapisan amil } \\
\text { alkohol (Alamsyah et al. 2014). }\end{array}$ & $(+)$ \\
\hline Alkaloid & $\begin{array}{l}\text { Tabung } 1 \rightarrow \text { Tidak } \\
\text { terbentuk Endapan } \\
\text { putih kekuningan } \\
\text { (Reagen Mayers). } \\
\text { Tabung } 2 \rightarrow \text { Tidak } \\
\text { terbentuk Endapan } \\
\text { merah kecoklatan } \\
\text { (Reagen Dragendroff) }\end{array}$ & $\begin{array}{l}\text { Terbentuk endapan menggumpal warna } \\
\text { putih kekuningan pada reagen Mayer dan } \\
\text { terbentuk endapan berwarna merah sampai } \\
\text { jingga kecoklatan pada reagen Dragendroff } \\
\text { (Alamsyah et al. 2014). }\end{array}$ & $(-)$ \\
\hline Saponin & $\begin{array}{l}\text { Tidak terbentuk busa } \\
\text { yang stabil }+1 \text { tetes } \\
\text { HCl } 2 \mathrm{~N} \text { busa tidak } \\
\text { hilang. }\end{array}$ & $\begin{array}{l}\text { Terbentuk busa yang stabil }+1 \text { tetes } \mathrm{HCl} \\
\text { 2N busa tidak hilang (Ramyashree } \text { et al. } \\
\text { 2012). }\end{array}$ & $(-)$ \\
\hline Tanin & $\begin{array}{l}\text { Terbentuk warna hijau } \\
\text { violet }\end{array}$ & $\begin{array}{l}\text { Hasil positif tannin jika terbentuk warna } \\
\text { hijau violet ( Depkes 1995). }\end{array}$ & $(+)$ \\
\hline Antosian & $\begin{array}{l}\text { Terbentuk warna } \\
\text { merah, warna tidak } \\
\text { pudar }\end{array}$ & $\begin{array}{l}\text { Hasil positif antosian warna tidak akan pudar } \\
\text { (Harborne, 1996). }\end{array}$ & $(+)$ \\
\hline
\end{tabular}


Fraksi etil asetat pada kelopak bunga rosela mempunyai kandungan flavonoid yang mempunyai potensi sebagai tabir surya karena memiliki gugus kromofor (ikatan rangkap tunggal terkonjugasi) yang mampu menyerap sinar UV-A maupun UV-B sehingga mengurangi intensitas pada kulit (Rahmawati, 2012). Antosianin merupakan suatu senyawa yang memiliki sistem ikatan rangkap terkonjugasi yang berperan mencegah kerusakan sel akibat paparan sinar UV berlebih. Tanin adalah senyawa yang bermanfaat sebagai tabir surya. Tanin terkondensasi memiliki aktivitas sebagai antioksidan dan dapat melindungi kulit dari kerusakan yang ditimbulkan radiasi ultraviolet (Brandt, 2000).

\section{SIMPULAN}

Nilai SPF dari ekstrak, fraksi nheksana, fraksi etil asetat dan fraksi air dari ekstrak bunga rosela yaitu berturut-turut $6,63 \pm 0,23 ; \quad 10,11 \pm 0,61 ; \quad 13,83 \pm 1,50$; $11,15 \pm 0,47$

Fraksi etil asetat adalah fraksi yang mempunyai nilai SPF tertinggi yang bisa dimanfaatkan sebagai tabir surya masuk kategori proteksi maksimal.

\section{UCAPAN TERIMAKASIH}

Terimakasih peneliti sampaikan kepada Universitas Setia Budi yang telah membiayai penelitian ini pada skema Penelitian Dasar tahun pendanaan 2020

\section{DAFTAR PUSTAKA}

Alamsyah HK, Widowati I, Sabdono A. 2014. Aktivitas antibakteri ekstrak rumput laut Sargassum cinereum (J.G. Agardh) dari perairan pulau panjang jepara terhadap bakteri Escherichia coli dan Staphylococcus epidermidis. Journal Of Marine Research 3:69-78

Anonim., 1986. Sediaan Galenik. Jakarta: Departemen Kesehatan Republik Indonesia. hlm 6-7, 10-12.

Brandt,S. 2000. Development of New quality Charateristic and Resulting Optimization of Sunscreens". Skin Care Forum, 23

Damogalad, V., Edy HJ., Supriati, 2013, Formulasi krim tabir surya ekstrak kulit nanas (Ananas Comosus L) dan uji in vitro nilai sun protecting factor ( SPF) Pharmacon. Jurnal Ilmiah Farmasi, UNSRAT. 2 (2): 12-16

Harborne JB. 1996. Metode Fitokimia: Penentuan Cara Modern Menganalisis Tumbuhan. penerjemah; K. Padmawinata. Bandung: Penerbit ITB. hlm. 47-51.

Harry, R.G., Wilkinson, J.B. \& Moore, R.J., 1982, Harry's Cosmeticology, 7th ed, 314-333, Chemical Publishing Company, New York.

Katno, Kusumadewi AW, Sutjipto. 2008. Pengaruh waktu pengeringan terhadap kadar tanin daun jati Belanda (Guazuma ulmifolia Lamk.). Jurnal Tumbuban Obat Indonesia 1: 3846.

Kuriyan, R.. Kumar, R.D., Rajendran, R., and Kurpad, V.A. 2010, BMC

Complementary and Alternative Medicine, 10:27

http://www.biomedcentral.com/147 2-6882/10/27

Mansur JS, et al. 1986., Determination of Sun Protection Factor for Spectrophotometry. An Bras Deramtol.; 61:121-124.

Markham, K.M., 1982, Techniques of Flavonoid Identification, diterjemahkan oleh Kosasih Padmawinata, 1988, ITB, Bandung, 1-103.

Maryani dan Kristiana, 2008, Khasiat dan Manfaat Rosela, Agro Media Pustaka, Jakarta, 6-29.

Mulyani, Armini Syamsidi, Pramita Putri., 2015., Penentuan Nilai SPF (Sun Protecting Factor) Ekstrak NHeksan Etanol Dari Rice Bran (Oryza Sativa) Secara In Vitro Dengan Metode Spektrofotometri UV-VIS Online Jurnal of Natural Science Vol 4(1) :89-95 ISSN: 23380950 Maret 2015

Mukhriani. 2014. Ekstraksi, pemisahan senyawa, dan identifikasi senyawa aktif. Jurnal Kesehatan 7:361-367.

Rahmawati, R., 2012., Budidaya Rosela. Yogyakarta: Pustaka Baru Press.

Ramyashree M, Krishna Ram H, Shivabasavaiah. 2012. Ethnomedicinal value of opunti elatior fruits and its effects in mice. 
Journal of Pharmacy Research 8: 4554-4558.

Shovyana, H.H., \& Zulkarnain, A.M., 2013., Stabilitas Fisik dan Aktivitas Krim W/O Ekstrak Etanolik Buah Mahkota Dewa (Phaleria macrocarpha) Sebagai Tabir Surya. Tradisional Medicine.

Steenis V.C.G.G.J dan D.den Hoed, S Bloembergen, P.J Eyma, 1992., Flora :untuk sekolah di Indonesia, diterjemahkan Moeso Surjowinoto, Penerbit Pradnya Paramita, Jakarta. Syamsuhidayat, S. S., Hutapea, J. R. 1991. Inventaris Tumbuhan Obat Indonesia, jilid 1, Depkes RI, Jakarta.

Tiwari P, Kumar B, Kaur M, Kaur G, Kaur H. 2011. Phytochemical screening and extractoin. Internationale Pharmacutica Sciecia 1:98-106.

Tomazelli L.C, Ramos M.M.A, Sauce R, Candido T.M, Sarruf F.D, Pinto C.A.S.O, Oliveira C.A, Rosado C, Velasco M.V.R, Baby A.R. 2018. SPF enhancement provided by rutin in a multifunctional sunscreen. International Journal of Pharmaceutics. Vol 552:1-2. 1 Desember 2018. 